\title{
Managing the Effluents of Anaerobic Fermentations by Bioprocess Schemes Involving Membrane Bioreactors and Bio-Electrochemical Systems: A Mini-Review
}

\author{
Gábor Z. Szelényi ${ }^{1, *(\mathbb{D})}$, Róbert Kurdi ${ }^{2}$, Nándor Nemestóthy ${ }^{1}$ (D) Katalin Bélafi-Bakó $^{1}$ and Péter Bakonyi $^{1}$ \\ 1 Research Group on Bioengineering, Membrane Technology and Energetics, University of Pannonia, \\ Egyetem ut 10, 8200 Veszprem, Hungary; nemesn@almos.uni-pannon.hu (N.N.); \\ bako@almos.uni-pannon.hu (K.B.-B.); bakonyip@almos.uni-pannon.hu (P.B.) \\ 2 Sustainability Solutions Research Laboratory, University of Pannonia, \\ Egyetem ut 10, 8200 Veszprem, Hungary; kurdi.robert@uni-pannon.hu \\ * Correspondence: szelenyi.gabor@mk.uni-pannon.hu
}

check for updates

Citation: Szelényi, G.Z.; Kurdi, R.; Nemestóthy, N.; Bélafi-Bakó, K.; Bakonyi, P. Managing the Effluents of Anaerobic Fermentations by Bioprocess Schemes Involving Membrane Bioreactors and Bio-Electrochemical Systems: A Mini-Review. Energies 2022, 15, 1643. https://doi.org/10.3390/ en15051643

Academic Editors:

Panagiotis Tsapekos and

Merlin Alvarado-Morales

Received: 12 January 2022

Accepted: 21 February 2022

Published: 23 February 2022

Publisher's Note: MDPI stays neutral with regard to jurisdictional claims in published maps and institutional affiliations.

Copyright: (C) 2022 by the authors. Licensee MDPI, Basel, Switzerland. This article is an open access article distributed under the terms and conditions of the Creative Commons Attribution (CC BY) license (https:// creativecommons.org/licenses/by/ $4.0 /)$.

\begin{abstract}
Anaerobic bioprocesses, such as anaerobic digestion and dark fermentation, provide energy carriers in the form of methane and hydrogen gases, respectively. However, their wastewater-type residues, that is, the fermentation effluents, must be treated carefully due to the incomplete and non-selective conversion of organic matter fed to the actual system. For these reasons, the effluents contain various secondary metabolites and unutilized substrate, in most cases. Only a fraction of anaerobic effluents can be directly applied for fertilization under a moderate climate. Conventional wastewater treatment technologies may be used to clean the remainder, but that approach leads to a net loss of energy and of potentially useful agricultural input materials (organic carbon and NPK fertilizer substitutes). The rationale of this paper is to provide an overview of promising new research results in anaerobic effluent management strategies as a part of technological downstream that could fit the concept of new-generation biorefinery schemes aiming towards zero-waste discharge, while keeping in mind environmental protection, as well as economical perspectives. According to the literature, the effluents of the two above processes can be treated and valorized relying either on membrane bioreactors (in case of anaerobic digestion) or bio-electrochemical apparatus (for dark fermentation). In this work, relevant findings in the literature will be reviewed and analyzed to demonstrate the possibilities, challenges, and useful technical suggestions for realizing enhanced anaerobic effluent management. Both membrane technology and bio-electrochemical systems have the potential to improve the quality of anaerobic effluents, either separately or in combination as an integrated system.
\end{abstract}

Keywords: anaerobic digestion; membrane bioreactor; hydrogen production; bio-electrochemical system; effluent treatment; integrated system

\section{Introduction}

Anaerobic digestion (AD) is recognized as a plausible option to treat solid wastes and wastewaters, and produce biogas (comprising mostly of methane and carbon dioxide) synchronously with the degradation of organic matter. AD has been routinely practiced in combination with membrane technology, forming systems called anaerobic membrane bioreactors (AnMBR). The various AnMBRs have been proven effective as integrated applications for the in-place management of the bioprocess effluent and possess multifold advantages, in particular (i) the adequate retention (recycling) of active biomass that can lead to improved biogas productivity; (ii) independent setting of hydraulic- and solid-retention times, giving an opportunity to aid the degradation of recalcitrant organic matter fractions; and (iii) the adjustment of permeate (the final effluent) quality (e.g., by retaining/recovering nitrogenous and phosphorous nutrients) in accordance with discharge 
specifications, aiming to achieve reduced environmental footprints [1-3]. For instance, the deployment of forward osmosis and membrane distillation was demonstrated to be successful in regaining purified water, as well as struvite, from digested sludge as a starting material [4]. AnMBRs can also be assisted by other e.g., chemical precipitation, methods to attain enhanced treatment efficiencies [5].

Dark fermentation has been at the forefront of renewable energy research due to its capacity to convert organics into a gas mixture with significant $\mathrm{H}_{2}$ content. However, the fermentation effluents contain compounds such as volatile fatty acids (VFAs) and hence need proper treatment. The fact that hydrogen fermentation effluents are rich in such substances makes them suitable feedstocks for microbial electrochemical technologies driven by the underlying electro-active bacteria or their consortia. Actually, bio-electrochemical systems, such as microbial fuel cells and microbial electrolysis cells, have been widely used to generate either electricity or hydrogen gas as products from particular hydrogen fermentation effluents [6-8].

The treatment and potential re-use of anaerobic effluents became a bottleneck in the rapidly growing biogas and bio-hydrogen industry. The aim of this paper is to review the potential of two groups of novel technologies that seem to be particularly promising for the environmentally friendly treatment of these effluents. Both membranes and bioelectrochemical systems are under extensive research and development, and this paper intends to review recent advances towards this specific goal.

Besides dark fermentation, the efficiency of several other bioconversion systems can be enhanced with the integration of bio-electrochemical systems. Electro-fermentation of commercially valuable organic substances, biomethanisation, aerobic and anaerobic biofiltration of high-strength organic wastewaters and sludge, even artificial wetlands and other rhizospheric water treatment installations are involved. These systems, however, exceed the scope of this mini-review.

In the next sections, the main technical characteristics, issues to be tackled, and improvement opportunities for the two anaerobic bioprocesses will be overviewed and detailed for providing compact and informative insights into the effluent treatment options lying in anaerobic membrane bioreactors or bioelelectrochemical systems, particularly microbial fuel cells. Both groups of technologies have been proven to improve the quality of anaerobic effluents at the laboratory scale. With the advancement of material science, microbiology, and three-dimensional computer-aided design, new membrane types, reactor configurations, system designs, and catalyzers are appearing very fast. As a consequence, industrial-scale application is lagging behind; therefore, little real substrate operational and performance data are available on these emerging technologies at present. Their economic feasibility cannot be included in the scope of this mini-review.

\section{Methodology for Article Selection}

As for the cited literature, a comprehensive search was conducted for ensuring sufficient diversity. In fact, taking into account the distribution of the papers selected for the analysis, approximately $70 \%$ of the references focus on the latest developments for providing state-of-the-art information (from the period of 2012-2021), with special emphasis given to works published in the last five years (approx. $40 \%$ of the references). Additionally, the articles included in our assessment were collected from a wide range of internationally recognized journals by surveying scientific databases, e.g., SCOPUS, using keywords relevant to the topic of "anaerobic membrane bioreactors", "fermentation effluents", and "bio-electrochemical systems" encompassing "microbial fuel cells". First, the filtering of the so-obtained list of papers was carried out considering the "Title" and the "Abstract". 


\section{Effluent Treatment of Biogas Production by Integrating Membranes with Anaerobic Digesters}

Membrane technology can be used for a variety of purposes in the post-treatment of anaerobic effluents, as seen in Figure 1 [3].

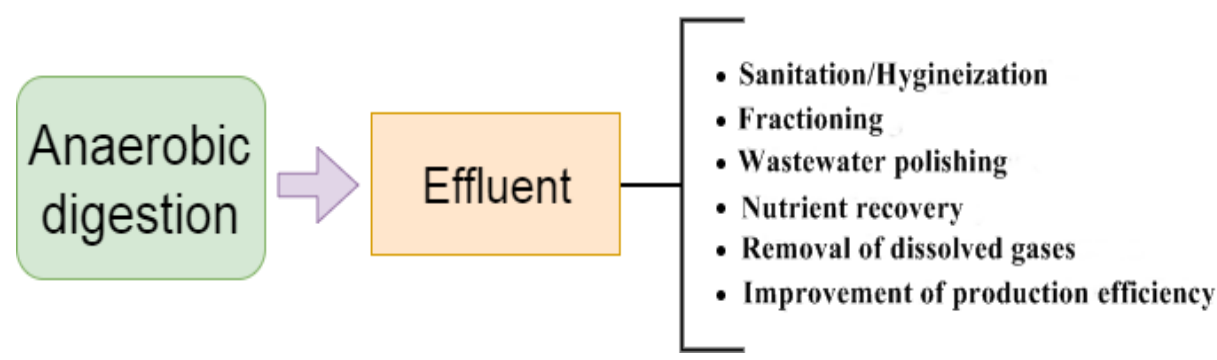

Figure 1. Potential roles of membranes in effluent treatment.

\subsection{AnMBR Configuration}

The basic scheme of a biogas-generating AnMBR applies a porous membrane linked to the (stirred) bioreactor. The cross-flow operation of the membrane is established by a suitable pressure gradient (using a pump) and, as a result, the concentrate returns to the bioreactor, while the permeate with improved quality is drawn. Usually, the membrane can either be of micro- or ultrafiltration-type, and its pore size has a direct impact on the filtration resistance and, concurrently, on the actual permeate flux [9]. In addition, other key features of the membrane, including its composition, inner- and surface structures, etc., also influence the performance and stability of filtration over time. To sustain the required level of permeate flux in longer terms, the (organic and inorganic) fouling occurring inevitably demands the choice of cleaning procedures, taking the membrane characteristics into consideration $[10,11]$. Although the full regeneration of the membrane is an unlikely realistic objective-since the fouling, to a certain extent, induces irreversible changes-high restoration degrees of the initial flux could be achieved, e.g., $96 \%$, as shown in the study of Jacob et al. [12]. Here, it is underlined that fouling is largely dependent on how the membrane is used and, thus, proper operating conditions, e.g., by programming switchon/switch-off cycles, can help to reduce its negative effect [13]. Besides, adjusting lower permeate fluxes may delay fouling and, consequently, the increase of hydraulic filtration resistance could be prolonged. In fact, it was reported by Zhang et al. [14] that the decline of filtrate flux was associated with the gradually increasing membrane resistance over a period of 135 days. After subjecting the membrane to chemical cleaning, its residual resistance was 30\% higher in comparison with that of the pristine membrane [14]. Apart from the strategies focusing on the operational part of the membrane, fouling could be mitigated by approaches purposefully modifying the composition of the feed stream. For instance, the loading of adsorbents (activated carbon and zeolite) and coagulants (PAC) to the fermentation liquor has been found to be beneficial to counteract membrane fouling because of the promoted aggregation and flocculation of components [15]. Furthermore, the effective preconditioning of the inlet flow by adjusting its $\mathrm{pH}$ to acidic values $(\mathrm{pH}=5)$ was documented by Yan et al. [16] to decrease the thickness of the fouling layer developing on the membrane's surface. Perspective non-chemical defouling methods include intermittent bubbling, where the recirculated biogas bubbles themselves remove foulants from a tilted membrane filter [17].

As it can be seen from the technical information in Table 1, most membranes used in the treatment of anaerobic digestion effluents are composed of several polymers and, in addition, inorganic (ceramic) membranes can also have relevance for the same purpose. Regardless of the materials, both the polymeric and inorganic membranes are fabricated, either as micro- or ultrafiltration modules, with pore sizes ranging typically from $30 \mathrm{~nm}$ to $450 \mathrm{~nm}$ or, alternatively, the rejection characteristics are described by the cut-off value. 
Table 1. Features of membranes applied in the treatment of anaerobic digester/bioreactor effluents.

\begin{tabular}{cccc}
\hline Material & Type & Pore Size & Reference \\
\hline Ceramic $\left(\alpha \mathrm{Al}_{2} \mathrm{O}_{3}\right.$ & Microfiltration & $200 \mathrm{~nm}$ & \\
with active $\mathrm{TiO}_{2}$ & Ultrafiltration & $50 \mathrm{~nm}$ & {$[9]$} \\
layer $)$ & Ultrafiltration & $20 \mathrm{kDa}$ cut-off & \\
\hline PVDF & Microfiltration & $450 \mathrm{~nm}$ & {$[11]$} \\
Polyethylene & Ultrafiltration & $30 \mathrm{~nm}$ & {$[13]$} \\
Polyethersulphone & Ultrafiltration & $20 \mathrm{kDa} \mathrm{cut}$ off & {$[14]$} \\
PVDF & Microfiltration & $220 \mathrm{~nm}$ & {$[15]$} \\
PVDF & Microfiltration & $450 \mathrm{~nm}$ & {$[16]$} \\
\hline
\end{tabular}

Technically speaking, a separate membrane unit is connected to the digester in most of the applications, as shown in Figure 2. The effluent is pumped to the membrane unit and the permeate is then evacuated from the system while the retentate is recirculated to the digester.

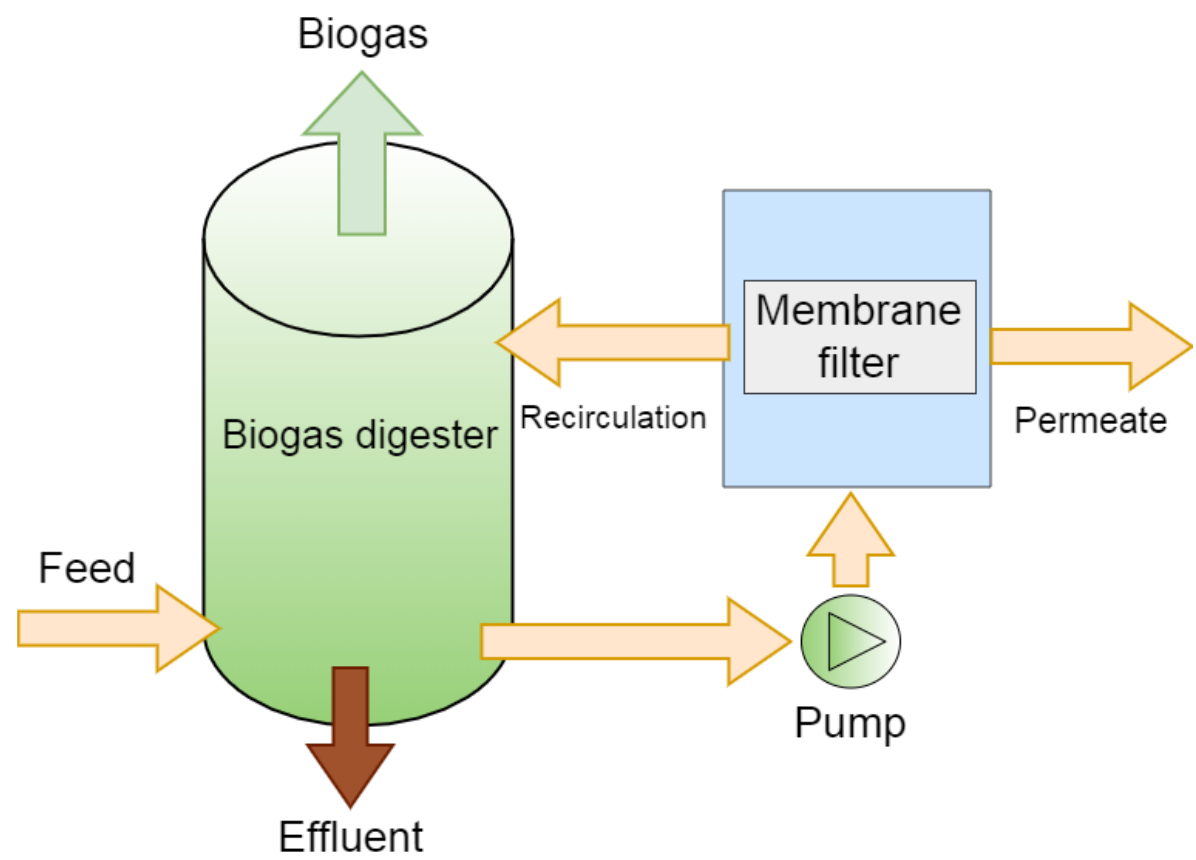

Figure 2. Scheme of a coupled-type AnMBR.

In AnMBRs, the permeate quality with regard to its organic matter content is often monitored via the BOD/COD ratio. Generally, the relatively high 0.6-0.8 BOD/COD in the feed of the AnMBR is favorable and indicates good biodegradability. On the contrary, permeate should have low a BOD/COD ratio, meaning that the biodegradable organic matter has been utilized well and an inert, hardly-convertible COD fraction is only left behind. Substances with low biodegradability under anaerobic conditions could be, for example, different pigments [18]. Still, quasi-stabilized permeates with a low BOD/COD ratio might be exploited as soil conditioners to aid humification [19]. To reach the desired permeate quality in the AnMBR and assist the balanced performance, the membrane filtration process can be designed as a cascade, where each step in the sequence is operated at its own optimum. A relevant example was demonstrated by Stamatelatou et al. [20], where the final permeate quality was set via the chain of filter pressing, ultrafiltration, and reverse osmosis.

To facilitate the proper decomposition of substrates into biogas, AnMBRs may be attached with pre- or post-treatment technologies. As a matter of fact, process perturbation can deteriorate the microbiological harmony of AnMBRs and, subsequently, metabolic 
and/or population shifts occur. A well-known example is related to the accumulation of volatile fatty acids and inherent acidification of the bioreactor, which act against the growth and activity of methane-forming archaea. To overcome this issue, separate acidogenesis (as pre-treatment) and methanogenesis can be proposed, in which a pre-digestate at a controlled loading rate is fed to produce biogas [21]. In the research of Ravi et al. [22], a two-stage system was suggested for proper biogas production using plant residues as a raw material. The effluent of the first, acidogenic reactor was filtered by a ceramic membrane and the permeate (with reduced particulate and inert organic matter content) was methanized in the second reactor, leading to $25-40 \%$ improvement in the methane yield.

Regarding the post-treatment units connected to AnMBRs, they play a role in removing certain components accumulating during biogas fermentation. Actually, one particular application field could be the removal of ammonium nitrogen $\left(\mathrm{NH}_{4}-\mathrm{N}\right)$ so as to (i) avoid the risk of process inhibition, (ii) adjust the permeate composition, and (iii) accomplish resource recovery. Physico-chemical treatment of the permeate from the AnMBR was implemented by Busato et al. [23] via combined air stripping and sulfuric acid dosing to obtain ammonium sulfate. Moreover, hydrophobic gas permeation membranes submerged into the fermentation liquor of AnMBR were investigated in the work of Bayrakdar et al. [24]. In contrast to the coupled configuration shown in Figure 2, the membrane may be integrated within the anaerobic digester, such as in the above case of $\mathrm{NH}_{4}-\mathrm{N}$ removal. The general scheme of such integrated membranes is presented in Figure 3.

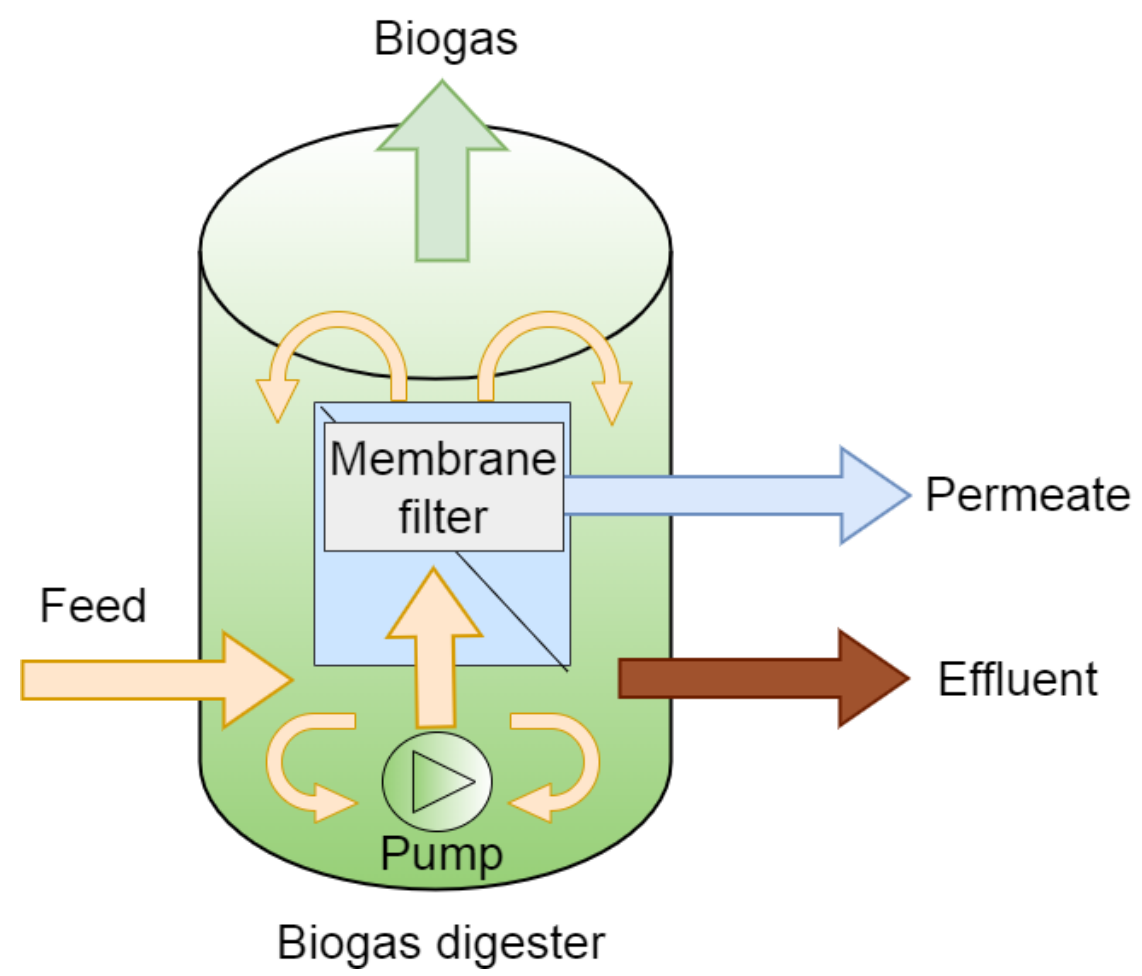

Figure 3. Scheme of an integrated AnMBR.

In such a system, the (porous) membrane (contactor) mediates the concentration differencedriven passage of dissolved ammonia to a strip solution (e.g., 0.2-0.3 $\mathrm{M} \mathrm{H}_{2} \mathrm{SO}_{4}$ ) [25]. The rate of ammonia removal can be affected by factors such as the effluent $\mathrm{pH}$ and the separation temperature [26]. Concerning the inhibition effect of ammonia on biogas production in AnMBRs, Shi et al. [27] concluded that the concentration of free ammonia reduced to $40 \mathrm{mg} \mathrm{N} \mathrm{L}^{-1}$ (instead of $70 \mathrm{mg} \mathrm{N} \mathrm{L}^{-1}$ ) by applying a membrane contactor was able to increase the relative abundance of methanogenic microbial communities and, consequently, the biogas productivity by $50-60 \%$. In view of the gases dissolved in the liquid phase of anaerobic digesters, the problems with methane have to be addressed. As remarkable quantities of $\mathrm{CH} 4$ can be present in 
the fermentation mixture and in the permeate of AnMBR, fluctuations in system performance are potential threats, even under steady-state conditions [28]. Losses of methane may not exclusively contribute to unstable operation, but, in addition, create negative environmental impacts due to the significant global warming potential of this compound (more than 20 times higher than that of $\mathrm{CO}_{2}$ ) [29]. Based on the literature, the deployment of non-porous, hydrophobic (e.g., PDMS) gas-liquid membrane contactors is a feasible solution for effective methane recovery from the effluents of anaerobic bioreactors [30,31]. Therefore, the controlled recovery of dissolved methane is key for the stabilization of the digester effluent, after which (thanks to its residual organic matter and nutrient contents) it can more safely undergo successive valorization to cultivate microalgae, for instance [32].

\subsection{AnMBR in Complex Systems}

In fact, microalgae, depending on the AD effluent composition and operational settings of the photobioreactor, are capable of utilizing the components with $\mathrm{N}$ - and P contents [33]. The harvesting of algal biomass could be conducted by ultrafiltration and, interestingly, Xie et al. [34] observed that the filtration cake over the membrane surface (consisting of Chlorella vulgaris and powdered activated carbon) prolonged the operation cycle by protecting the membrane better from fouling. For algal membrane photobioreactors exploiting anaerobic fermentation effluents, it is crucial to find operating strategies and technological schemes that can effectively deal with their varying qualities in terms of their occasional toxicity and adverse optical properties [35,36]. Microalgae-based integrated systems for the closed-loop treatment of anaerobic effluents (coming from biohydrogen fermenters) have been proposed by various papers, e.g., Bakonyi et al. [37]. Figure 4 represents the scheme of this circular treatment system:

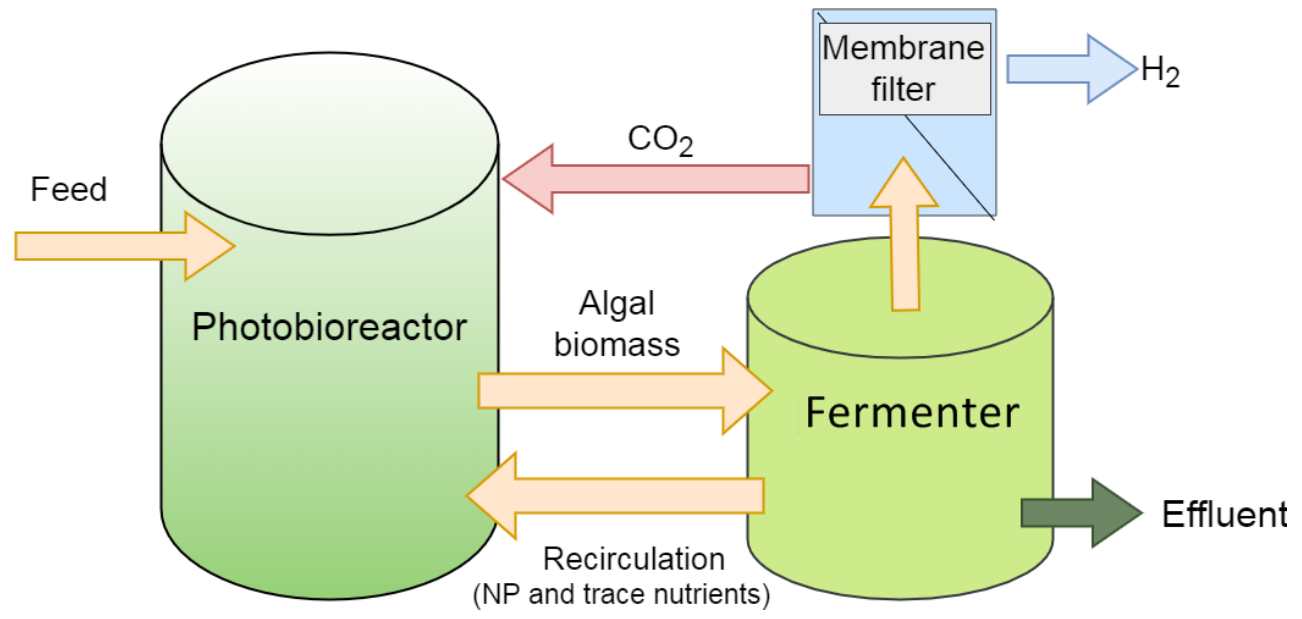

Figure 4. Closed-loop effluent treatment [36].

It is noteworthy that membrane contactors could be employed not only for methane recovery, but also for intensifying anaerobic digesters via boosting hydrogenotrophic methanogenesis as a result of better feed gas $\left(\mathrm{H}_{2} / \mathrm{CO}_{2}\right)$ delivery in the frame of the socalled power-to-gas concept [38,39].

\section{Bio-Electrochemical Systems (BES) for the Treatment of Dark Fermentative Hydrogen Production Effluents}

The conversion efficiency of various biological systems can be enhanced if assisted by integrated bio-electrochemical systems. This effect is due to:

- $\quad$ Simultaneous occurrence of different (and usually subsequent) phases of the redox processes in electrically linked distant spaces of the reactor, which, in practice, behaves as an additional stirring, 
- Leveraging effect of the additional electric potential on the biochemical processes; this allows complementary endotherm reactions that would not occur in the absence of external potential,

- A supplementary selection advantage of electro-active microbial strains that increases the variety of organic compounds to biodegrade.

- Among the possible biological systems, the bio-electrochemical assistance to dark fermentation is reviewed in the following section.

\subsection{BES Configurations}

Both microbial fuel cells (MFC) and microbial electrolysis cells (MEC) break down organic compounds by removing hydrogen from molecules. The exo-electrogenic microorganisms transfer the removed electrons to a positively charged anode, while the corresponding protons are ejected to the medium. These protons migrate to the cathode through a cation exchange membrane, while the electrons do the same through an external circuit. The difference is that, in an MFC, the protons and electrons recombine with oxygen, where the redox reaction supplies the necessary energy. Meanwhile, in the MEC, they recombine with each other, the necessary energy being supplied by external electric power. The two systems are compared in Figures 5 and 6.

In accordance with the literature, the composition of the dark fermentation effluent (the concentration and relative ratio of VFAs) can vary depending on the actual hydrogen fermentation conditions [40] and, thus, it can take an effect on the achievable electron recovery efficiency and electrochemical performance of microbial fuel cells [41]. Apart from the VFAs (acetic acid, propionic acid, and butyric acid), the hydrogen fermentation effluent may contain lactate, valeric acid, capronic acid, ethanol, etc. [42]. Although VFAs are generally favored substances for electro-active strains, the type of VFA (e.g., acetic acid vs. butyric acid) can notably determine the microbial fuel cell performance [43]. In the study of Kiely et al. [44], it was inferred from the results of a year of experimentation in a microbial fuel cell that the distribution of $\mathrm{H}_{2}$ fermentation dead-end products (e.g., formic acid, acetic acid, lactic acid, and succinic acid) played a major role pertaining to the obtainable process efficacy.

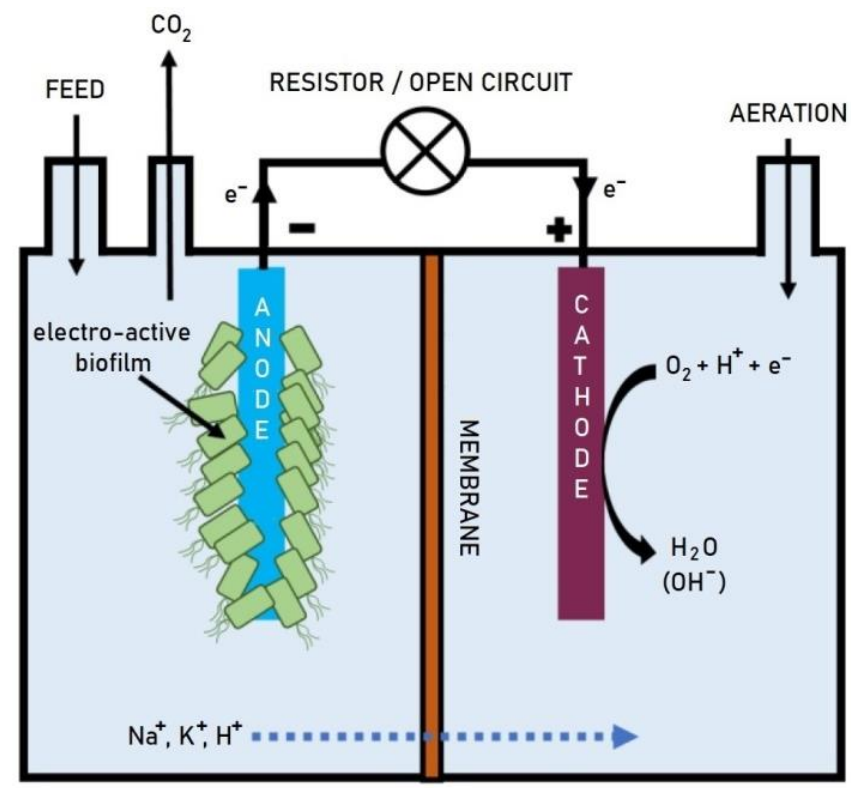

Figure 5. MFC. 


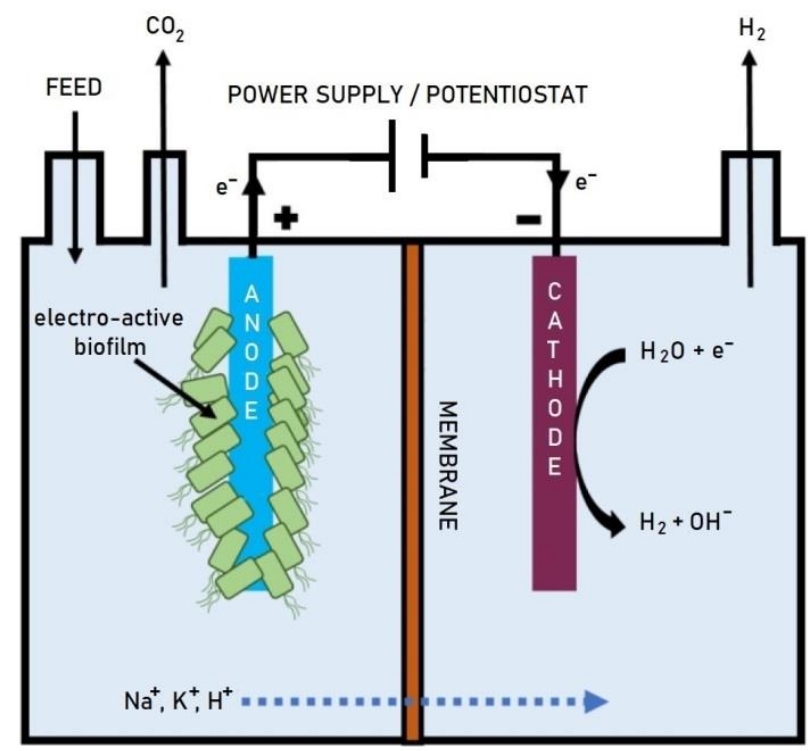

Figure 6. MEC.

From a taxonomic viewpoint, to increase MFC performance, species belonging to the genus Geobacter should be promoted in the anodic biofilm keeping in mind that the corresponding species may reflect distinct metabolic versatilities and hence affect system behavior [45]. In this aspect, when the feed of MFCs contains complex organic matter that electro-active microorganisms might be insufficient to deal with directly, rate limitations may arise from the preliminary hydrolysis/conversion steps [46]. For cases when MFCs meet complex feedstocks, mixed-source inocula could be viable to select and adapt the required (synergistic) microbes; defined co-cultures accommodating taskspecific bacteria seem to be applicable as well. As for co-culture deployment in MFCs, Ren et al. [47] provided evidence for the feasibility of electricity generation in line with cellulose degradation using Clostridium cellulolyticum and Geobacter sulfurreducens. In another work [48], the constructed co-culture of Shewanella oneidensis and Klebsiella pneumonae was applied with success to convert glycerol into electricity in MFCs.

\subsection{BES in Complex Systems}

In addition to the engineering and design of effective exo-electrogenic communities in MFCs, pre-treatments can be considered for enhancing the degradation of complex materials. A pre-treatment may include fermentation or digestion, as shown, for instance, in the research of Chookaew et al. [49] and Kannaiah Goud and Venkata Mohan [50] on glycerol (the by-product of biodiesel production) and food waste, respectively. Chandrasekhar and Ahn [51] also proposed the pre-fermentation of piggery wastewater in order to increase the concentration of VFAs in the subsequent feed of MFCs. For high-organic-strength wastes, e.g., food waste, dilution with other, less-concentrated wastewaters could also be a practical approach to maintain proper MFC operation [52]. The scheme of this system can be drafted as oi Figure 7.

Though MFCs could have the potential to process wastes of the food industry e.g., cheese whey [53], treatments prior to the bio-electrochemical systems may further improve their working efficiency on such substrates [54,55]. A cornerstone of wastewater e.g., fermentation effluent management in MFCs, is the electrical conductivity of the solution, which is often low and may reduce the power density. To resolve this issue, salts might be added; however, some constraints can be faced by up-scaling the process and the tolerance of electro-active species to higher ion concentrations is a factor to be taken into account as well [56]. It is important to mention that MFCs, as pollutant treatment units of anaerobic effluents, can find a niche not only for organic matter degradation, but also for ammonia removal [57]. 


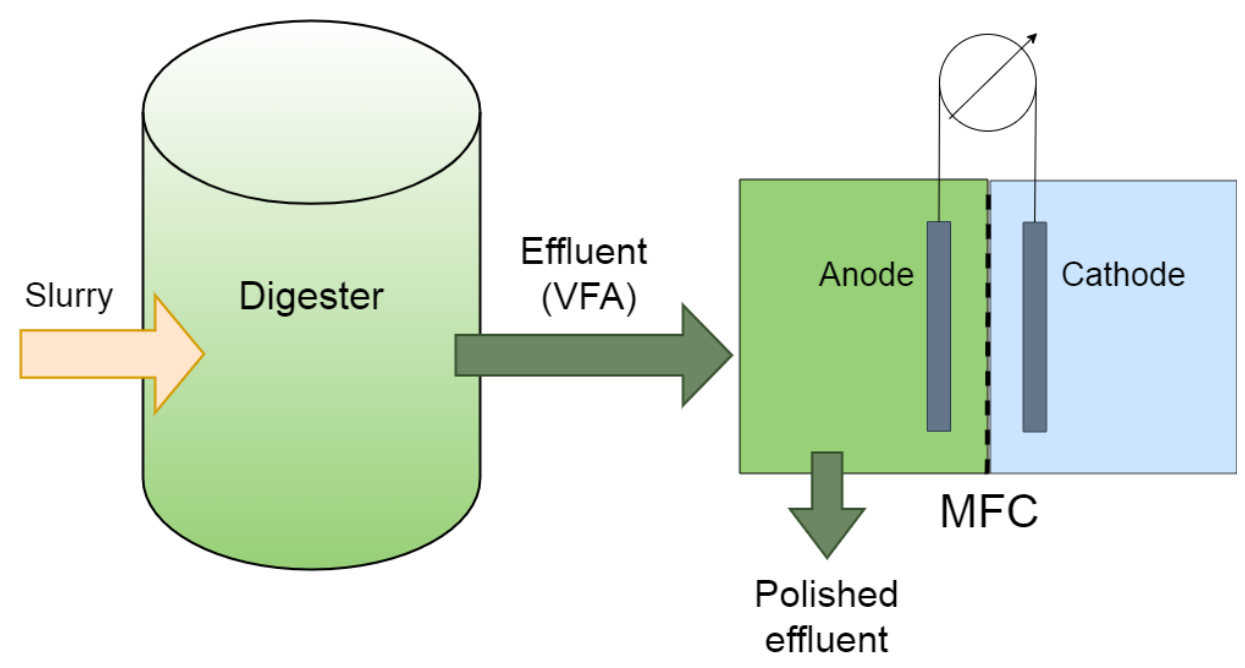

Figure 7. Pre-treatment of slurry in a biogas digester.

The performance of a wide range of bioprocesses can be largely improved if hybridized with bio-electrochemical systems [58], as seen in Figure 8.

Bioprocesses

- Biohydrogen fermentation

- Biogas digestion

- Fermentation/Electrofermentation

- Constructed wetland

- Bioremediation

- Membrane-assisted biotechnics

\section{Electrochemical} booster

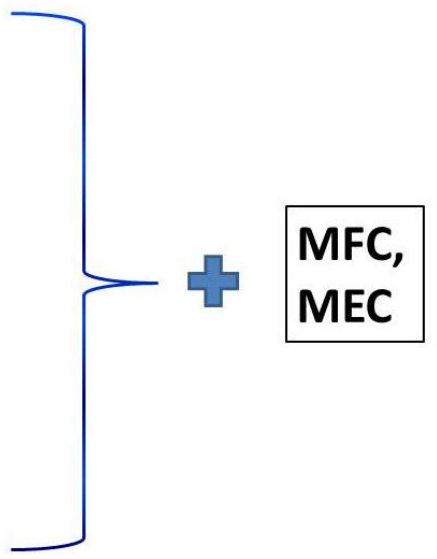

Figure 8. Potential bio-electrochemically boosted processes.

As MFCs have been proven suitable for coupling with other physical, chemical, and biological systems [58], their direct integration with dark fermentative $\mathrm{H}_{2}$ fermenters can be possible [59]. Such two-stage processes were illustrated in papers by Sharma and $\mathrm{Li}$ [60] and Varanasi et al. [61]. In the latter investigation, for instance, following $\mathrm{H}_{2}$ fermentation with a yield of $2.92 \mathrm{~mol} \mathrm{H}_{2} / \mathrm{mol}$ cellobiose substrate, the MFC receiving the effluent ensured $75 \%$ COD removal, $13 \%$ Coulombic efficiency, and $85 \mathrm{~mW} / \mathrm{m}^{2}$ maximal power density [61]. To enhance the MFC performance on dark fermentation effluent, centrifugation, $\mathrm{pH}$ adjustment and dilution may be viewed as adequate pre-treatments [62]. Recently, Song et al. [63] carried out extensive research on dual-stage $\mathrm{H}_{2}$ fermenter-MFC systems towards more complete conversion of algal biomass feedstock and revealed the contribution of each step by monitoring the fate of the carbohydrate, lipid, and protein contents throughout the operation.

Several biological conversion steps may also be linked to a cascade where each step is fed with the effluent of the previous one to decompose residual organic matter while producing a different energy carrier. For instance, Rózsenberszki et al. produced biohydrogen from municipal solid waste press liquor in the first step, and then the effluent passed through a biogas digester. [6] The remaining effluent was finally introduced to a microbial 
fuel cell to produce electricity while breaking down residual organic matter. While the bulk of the conversion took place in the biogas digester, both the previous and the subsequent step contributed to the overall conversion, as presented in Figure 9.

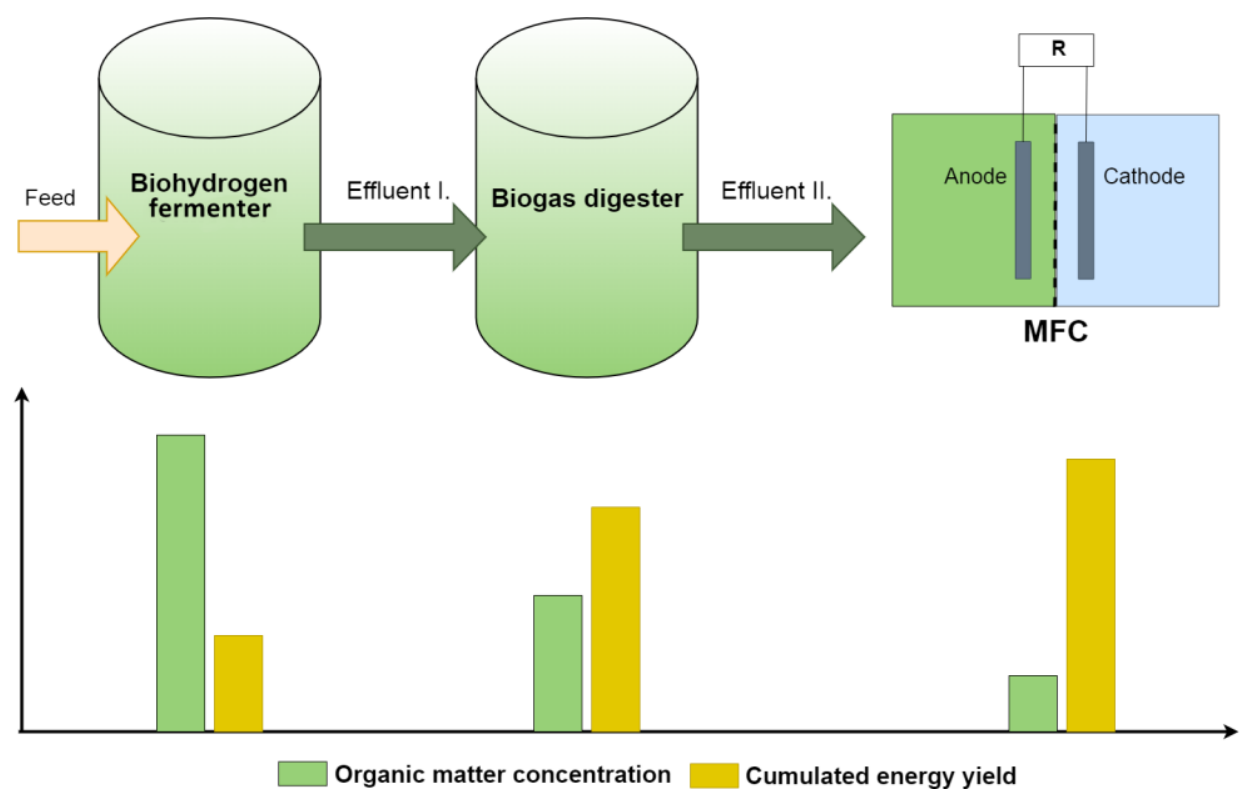

Figure 9. Conversion scheme of cascade biosystems.

By connecting more MFCs together, the global power production of the stacked (and scaled-up) configuration operated in the continuous mode could be improved [64]; however, efforts will be needed to eliminate limitations originating from the voltage reversal phenomenon [65].

While the reviewed bio-electrochemical systems are under extensive study at the laboratory scale, they have not attained industrial-scale application yet. The vast majority of the experiments use synthetic wastewaters in order to reduce the number of parameters to monitor. In addition, the overall performance of a bio-electrochemical system is the sum of several factors, such as Coulombic efficiency, anodic or cathodic current density, anodic or cathodic power density, where the density is variably measured either against electrode surface or electrolyte volume. The performance is sometimes expressed as the efficiency of nutrient recovery or pollutant removal, too. Different methods are used to measure the different components of performance, in accordance with the purpose of a given study; the scientific community has not yet reached a consensus on this issue. The Because of this large diversity, the experimental results are hardly comparable; therefore this mini-review does not intend to assess the efficiency of bio-electrochemical systems. Still, such evaluation will be an important condition for scaling up and technological implementation in the future.

\section{Conclusions}

In this work, the treatment possibilities of anaerobic fermentation effluents regarding biogas and biohydrogen production were concisely reviewed. Conventional wastewater technologies, such as an improved activated sludge method, can be effective as environmentally sound post-treatment for anaerobic effluents. However, they present the double disadvantage of requiring an additional carbon source for denitrification and of losing agriculturally useful nitrogen compounds by converting them to $\mathrm{N}_{2}$ gas [66]. Likewise, by biodegrading an unnecessary portion of the polluting organic matter and releasing the carbon content as $\mathrm{CO}_{2}$ to the atmosphere, they lose organic carbon compounds that could serve as much-needed humus precursors in cultivated soils [19]. In addition, a non-negligible proportion of the $\mathrm{CH}_{4}$ produced in biogas digesters remains dissolved in 
the effluent. It is not only a loss of energy, but also emits a severe greenhouse-effect gas to the atmosphere as air pollution [30].

Although in different ways, both membrane technology and bio-electrochemical systems have the potential to improve the quality of anaerobic effluents. It was shown that, beyond retaining the working microbial biomass in the system, anaerobic membrane bioreactors could be used to manage anaerobic digestion effluents by separating residual nutrients that are difficult to handle otherwise. This makes the process more attractive from environmental and production efficiency viewpoints. Due to issues with membrane fouling, opportunities for pre- and post-treatments schemes have been analyzed. As for dark fermentation, it was determined from the literature that microbial fuel cells, as a class of bio-electrochemical systems, could provide a sufficient platform to valorize the organic matter found in the $\mathrm{H}_{2}$ production effluent. Such valorization may be implemented either by microbial fuel cells to produce electricity, or by microbial electrolysis cells to produce additional hydrogen gas. Alternatively, MEC may be used to improve the energy conversion efficiency in biogas applications, as well. Suggestions to attain process enhancement in MFCs treating the effluent have been presented and concepts of integrated applications were outlined.

Beyond the above reviewed applications, bio-electrochemical systems are a promising tool to enhance the efficiency of other bioconversion systems, if combined. The Research Group on Bioengineering, Membrane Technology and Energetics at the University of Pannonia (Veszprém, Hungary) is among those institutions that endeavor at studying such integration opportunities. These studies involve electrically assisted bio-methanisation, biofiltration and rhizospheric wastewater treatment in particular. As soon as conclusive results obtained, they will be published in a separate paper. Although bio-electrochemical systems are extensively researched at the laboratory scale, they have not reached the industrial implementation scale yet. Reactor configuration, catalyzers, electrode materials, and electro-active microbial strains represent major upscaling challenges.

The reviewed processes have already proven their potential utility

- To recover nutrients;

- To recover waste methane;

- To remove residual pollutants from anaerobic effluents;

- To increase the bioconversion efficiency of anaerobic systems.

Further research in material science and microbiology, computer-aided modelisation and design is needed for scaling them up to the industrial level. Studying their economic feasibility will become necessary when the first industrial-scale applications appear. A primary condition to such scale-up is to express the research results in a more comparable way. This necessitates a future consensus to attain within the scientific community, on the smallest possible number of the most practical indicators.

Author Contributions: Conceptualization, P.B.; writing-original draft preparation, P.B.; writingreview and editing, G.Z.S.; visualization, G.Z.S.; supervision, N.N. and K.B.-B.; project administration, R.K.; funding acquisition, N.N. and K.B.-B. All authors have read and agreed to the published version of the manuscript.

Funding: This research work was supported by the project entitled "Establishment of a National Multidisciplinary Laboratory for Climate Change", No. NKFIH-471-3/2021, by the government of Hungary.

Institutional Review Board Statement: Not applicable.

Informed Consent Statement: Not applicable.

Data Availability Statement: Not applicable.

Acknowledgments: This work was partly supported by the K 138232 project entitled "Study of anaerobic effluent demethanization by membrane contactors in a novel, integrated bioprocess" financed by the National Research, Development, and Innovation Fund of Hungary. 
Conflicts of Interest: The authors declare no conflict of interest. The funders had no role in the design of the study; in the collection, analyses, or interpretation of data; in the writing of the manuscript, or in the decision to publish the results.

\section{References}

1. Kim, S.; Lee, D.W.; Cho, J. Application of direct contact membrane distillation process to treat anaerobic digestate. J. Membr. Sci. 2016, 511, 20-28. [CrossRef]

2. Collivignarelli, M.C.; Bertanza, G.; Abbà, A.; Sordi, M.; Pedrazzani, R. Synergy between anaerobic digestion and a post-treatment based on Thermophilic Aerobic Membrane Reactor (TAMR). Environ. Prog. Sustain. Energy 2017, 36, 1802-1809. [CrossRef]

3. Rongwong, W.; Lee, J.; Goh, K.; Karahan, H.E.; Bae, T.-H. Membrane-based technologies for post-treatment of anaerobic effluents. NPJ Clean Water 2018, 1, 21. [CrossRef]

4. Xie, M.; Nghiem, L.D.; Price, W.E.; Elimelech, M. Toward Resource Recovery from Wastewater: Extraction of Phosphorus from Digested Sludge Using a Hybrid forward Osmosis-Membrane Distillation Process. Environ. Sci. Technol. Lett. 2014, 1, 191-195. [CrossRef]

5. Kuglarz, M.; Grúbel, K.; Bohdziewicz, J. Chemical precipitation and ammonia air stripping as effective pre-treatment methods before membrane filtration of co-digestion effluents. Desalination Water Treat. 2014, 55, 1672-1682. [CrossRef]

6. Rózsenberszki, T.; Koók, L.; Bakonyi, P.; Nemestóthy, N.; Logroño, W.; Pérez, M.; Urquizo, G.; Recalde, C.; Kurdi, R.; Sarkady, A Municipal waste liquor treatment via bio-electrochemical and fermentation $\left(\mathrm{H}_{2}+\mathrm{CH}_{4}\right)$ processes: Assessment of various technological sequences. Chemosphere 2017, 171, 692-701. [CrossRef]

7. Bakonyi, P.; Dharmaraja, J.; Shobana, S.; Koók, L.; Rózsenberszki, T.; Nemestóthy, N.; Banu J, R.; Bélafi-Bakó, K.; Kumar, G Leachate valorization in anaerobic biosystems: Towards the realization of waste-to-energy concept via biohydrogen, biogas and bio-electrochemical processes. Int. J. Hydrogen Energy 2019, 44, 17278-17296. [CrossRef]

8. Bakonyi, P.; Kumar, G.; Koók, L.; Tóth, G.; Rózsenberszki, T.; Bélafi-Bakó, K.; Nemestothy, N. Microbial electrohydrogenesis linked to dark fermentation as integrated application for enhanced biohydrogen production: A review on process characteristics, experiences and lessons. Bioresour. Technol. 2018, 251, 381-389. [CrossRef]

9. Waeger, F.; Delhaye, T.; Fuchs, W. The use of ceramic microfiltration and ultrafiltration membranes for particle removal from anaerobic digester effluents. Sep. Purif. Technol. 2010, 73, 271-278. [CrossRef]

10. Kang, I.-J.; Yoon, S.-H.; Lee, C.-H. Comparison of the filtration characteristics of organic and inorganic membranes in a membranecoupled anaerobic bioreactor. Water Res. 2002, 36, 1803-1813. [CrossRef]

11. Yan, Z.; Yang, H.; Qu, F.; Zhang, H.; Rong, H.; Yu, H.; Liang, H.; Ding, A.; Li, G.; Van der Bruggen, B. Application of membrane distillation to anaerobic digestion effluent treatment: Identifying culprits of membrane fouling and scaling. Sci. Total Environ. 2019, 688, 880-889. [CrossRef]

12. Jacob, P.; Phungsai, P.; Fukushi, K.; Visvanathan, C. Direct contact membrane distillation for anaerobic effluent treatment. J. Membr. Sci. 2015, 475, 330-339. [CrossRef]

13. Wen, C.; Huang, X.; Qian, Y. Domestic wastewater treatment using an anaerobic bioreactor coupled with membrane filtration. Process Biochem. 1999, 35, 335-340. [CrossRef]

14. Zhang, J.; Padmasiri, S.; Fitch, M.; Norddahl, B.; Raskin, L.; Morgenroth, E. Influence of cleaning frequency and membrane history on fouling in an anaerobic membrane bioreactor. Desalination 2007, 207, 153-166. [CrossRef]

15. Wu, B.; An, Y.; Li, Y.; Wong, F.S. Effect of adsorption/coagulation on membrane fouling in microfiltration process post-treating anaerobic digestion effluent. Desalination 2009, 242, 183-192. [CrossRef]

16. Yan, Z.; Liu, K.; Yu, H.; Liang, H.; Xie, B.; Li, G.; Qu, F.; van der Bruggen, B. Treatment of anaerobic digestion effluent using membrane distillation: Effects of feed acidification on pollutant removal, nutrient concentration and membrane fouling. Desalination 2019, 449, 6-15. [CrossRef]

17. Annuar, A.M.; Nawi, N.I.M.; Bilad, M.R.; Jaafar, J.; Marbelia, L.; Nandianto, A.B.D. Improved bubbling for membrane fouling control in filtration of palm oil mill effluent anaerobic digester sludge. J. Water Process Eng. 2020, 36, 101350. [CrossRef]

18. Wijekoon, K.C.; Visvanathan, C.; Abeynayaka, A. Effect of organic loading rate on VFA production, organic matter removal and microbial activity of a two-stage thermophilic anaerobic membrane bioreactor. Bioresour. Technol. 2011, 102, 5353-5360. [CrossRef]

19. Szelényi, G.; Bakonyi, P.; Nemestóthy, N. Aerobic stabilization of organic waste effluents from anaerobic treatment for agricultural use. Desalination Water Treat. 2020, 192, 424-430. [CrossRef]

20. Stamatelatou, K.; Kopsahelis, A.; Blika, P.; Paraskeva, C.; Lyberatos, G. Anaerobic digestion of olive mill wastewater in a periodic anaerobic baffled reactor (PABR) followed by further effluent purification via membrane separation technologies. J. Chem. Technol. Biotechnol. 2009, 84, 909-917. [CrossRef]

21. Saddoud, A.; Sayadi, S. Application of acidogenic fixed-bed reactor prior to anaerobic membrane bioreactor for sustainable slaughterhouse wastewater treatment. J. Hazard. Mater. 2007, 149, 700-706. [CrossRef] [PubMed]

22. Ravi, P.P.; Merkle, W.; Tuczinski, M.; Saravia, F.; Horn, H.; Lemmer, A. Integration of membrane filtration in two-stage anaerobic digestion system: Specific methane yield potentials of hydrolysate and permeate. Bioresour. Technol. 2019, 275, 138-144. [CrossRef]

23. Busato, C.J.; Da Ros, C.; Pellay, R.; Barbierato, P.; Pavan, P. Anaerobic membrane reactor: Biomethane from chicken manure and high-quality effluent. Renew. Energy 2020, 145, 1647-1657. [CrossRef] 
24. Bayrakdar, A.; Sürmeli, R.Ö.; Calli, B. Dry anaerobic digestion of chicken manure coupled with membrane separation of ammonia. Bioresour. Technol. 2017, 244, 816-823. [CrossRef] [PubMed]

25. Dube, P.; Vanotti, M.; Szogi, A.; González, M.C.G. Enhancing recovery of ammonia from swine manure anaerobic digester effluent using gas-permeable membrane technology. Waste Manag. 2016, 49, 372-377. [CrossRef] [PubMed]

26. Wäeger-Baumann, F.; Fuchs, W. The Application of Membrane Contactors for the Removal of Ammonium from Anaerobic Digester Effluent. Sep. Sci. Technol. 2012, 47, 1436-1442. [CrossRef]

27. Shi, X.; Zuo, J.; Zhang, M.; Wang, Y.; Yu, H.; Li, B. Enhanced biogas production and in situ ammonia recovery from food waste using a gas-membrane absorption anaerobic reactor. Bioresour. Technol. 2019, 292, 121864. [CrossRef]

28. Jeong, E.; Kim, H.W.; Nam, J.-Y.; Shin, H.-S. Enhancement of bioenergy production and effluent quality by integrating optimized acidification with submerged anaerobic membrane bioreactor. Bioresour. Technol. 2010, 101, S7-S12. [CrossRef]

29. Heile, S.; Chernicharo, C.; Brandt, E.; McAdam, E. Dissolved gas separation for engineered anaerobic wastewater systems. Sep. Purif. Technol. 2017, 189, 405-418. [CrossRef]

30. Cookney, J.; Mcleod, A.; Mathioudakis, V.; Ncube, P.; Soares, A.; Jefferson, B.; McAdam, E. Dissolved methane recovery from anaerobic effluents using hollow fibre membrane contactors. J. Membr. Sci. 2016, 502, 141-150. [CrossRef]

31. Rongwong, W.; Goh, K.; Bae, T.-H. Energy analysis and optimization of hollow fiber membrane contactors for recovery of dissolve methane from anaerobic membrane bioreactor effluent. J. Membr. Sci. 2018, 554, 184-194. [CrossRef]

32. Cheng, J.; Ye, Q.; Xu, J.; Yang, Z.; Zhou, J.; Cen, K. Improving pollutants removal by microalgae Chlorella PY-ZU1 with $15 \%$ CO 2 from undiluted anaerobic digestion effluent of food wastes with ozonation pretreatment. Bioresour. Technol. 2016, 216, 273-279. [CrossRef] [PubMed]

33. Ruiz-Martinez, A.; Garcia, N.M.; Romero, I.; Seco, A.; Ferrer, J. Microalgae cultivation in wastewater: Nutrient removal from anaerobic membrane bioreactor effluent. Bioresour. Technol. 2012, 126, 247-253. [CrossRef] [PubMed]

34. Xie, B.; Gong, W.; Yu, H.; Tang, X.; Yan, Z.; Luo, X.; Gan, Z.; Wang, T.; Li, G.; Liang, H. Immobilized microalgae for anaerobic digestion effluent treatment in a photobioreactor-ultrafiltration system: Algal harvest and membrane fouling control. Bioresour. Technol. 2018, 268, 139-148. [CrossRef]

35. Chen, X.; Li, Z.; He, N.; Zheng, Y.; Li, H.; Wang, H.; Wang, Y.; Lu, Y.; Li, Q.; Peng, Y. Nitrogen and phosphorus removal from anaerobically digested wastewater by microalgae cultured in a novel membrane photobioreactor. Biotechnol. Biofuels 2018, 11, 190. [CrossRef] [PubMed]

36. Siegrist, H.; Hunziker, W.; Hofer, H. Anaerobic digestion of slaughterhouse waste with UF-membrane separation and recycling of permeate after free ammonia stripping. Water Sci. Technol. 2005, 52, 531-536. [CrossRef] [PubMed]

37. Bakonyi, P.; Kumar, G.; Bélafi-Bakó, K.; Kim, S.-H.; Koter, S.; Kujawski, W.; Nemestóthy, N.; Peter, J.; Pientka, Z. A review of the innovative gas separation membrane bioreactor with mechanisms for integrated production and purification of biohydrogen Bioresour. Technol. 2018, 270, 643-655. [CrossRef]

38. Ojeda, F.; Bakonyi, P.; Buitrón, G. Improvement of methane content in a hydrogenotrophic anaerobic digester via the proper operation of membrane module integrated into an external-loop. Bioresour. Technol. 2017, 245, 1294-1298. [CrossRef]

39. Wahid, R.; Mulat, D.G.; Gaby, J.C.; Horn, S.J. Effects of $\mathrm{H}_{2}: \mathrm{CO}_{2}$ ratio and $\mathrm{H}_{2}$ supply fluctuation on methane content and microbial community composition during in-situ biological biogas upgrading. Biotechnol. Biofuels 2019, 12, 104. [CrossRef]

40. Bakonyi, P.; Nemestothy, N.; Simon, V.; Bélafi-Bakó, K. Review on the start-up experiences of continuous fermentative hydrogen producing bioreactors. Renew. Sustain. Energy Rev. 2014, 40, 806-813. [CrossRef]

41. Teng, S.-X.; Tong, Z.-H.; Li, W.-W.; Wang, S.-G.; Sheng, G.-P.; Shi, X.-Y.; Liu, X.-W.; Yu, H.-Q. Electricity generation from mixed volatile fatty acids using microbial fuel cells. Appl. Microbiol. Biotechnol. 2010, 87, 2365-2372. [CrossRef] [PubMed]

42. Pasupuleti, S.B.; Srikanth, S.; Mohan, S.V.; Pant, D. Continuous mode operation of microbial fuel cell (MFC) stack with dual gas diffusion cathode design for the treatment of dark fermentation effluent. Int. J. Hydrogen Energy 2015, 40, 12424-12435. [CrossRef]

43. Liu, H.; Cheng, S.; Logan, B.E. Production of Electricity from Acetate or Butyrate Using a Single-Chamber Microbial Fuel Cell. Environ. Sci. Technol. 2005, 39, 658-662. [CrossRef] [PubMed]

44. Kiely, P.D.; Rader, G.; Regan, J.M.; Logan, B.E. Long-term cathode performance and the microbial communities that develop in microbial fuel cells fed different fermentation endproducts. Bioresour. Technol. 2011, 102, 361-366. [CrossRef] [PubMed]

45. Aklujkar, M.; Krushkal, J.; DiBartolo, G.; Lapidus, A.; Land, M.L.; Lovley, D.R. The genome sequence of Geobacter metallireducens: Features of metabolism, physiology and regulation common and dissimilar to Geobacter sulfurreducens. BMC Microbiol. 2009, 9, 109. [CrossRef] [PubMed]

46. Vázquez-Larios, A.L.; Solorza-Feria, O.; Vázquez-Huerta, G.; Esparza-García, F.; Rinderknecht-Seijas, N.; Poggi-Varaldo, H.M. Effects of architectural changes and inoculum type on internal resistance of a microbial fuel cell designed for the treatment of leachates from the dark hydrogenogenic fermentation of organic solid wastes. Int. J. Hydrogen Energy 2011, 36, 6199-6209. [CrossRef]

47. Ren, Z.; Ward, T.E.; Regan, J.M. Electricity Production from Cellulose in a Microbial Fuel Cell Using a Defined Binary Culture. Environ. Sci. Technol. 2007, 41, 4781-4786. [CrossRef]

48. Kim, C.; Song, Y.E.; Lee, C.R.; Jeon, B.-H.; Kim, J.R. Glycerol-fed microbial fuel cell with a co-culture of Shewanella oneidensis MR-1 and Klebsiella pneumonae J2B. J. Ind. Microbiol. Biotechnol. 2016, 43, 1397-1403. [CrossRef]

49. Chookaew, T.; Prasertsan, P.; Ren, Z.J. Two-stage conversion of crude glycerol to energy using dark fermentation linked with microbial fuel cell or microbial electrolysis cell. New Biotechnol. 2014, 31, 179-184. [CrossRef] 
50. Goud, R.K.; Mohan, S.V. Pre-fermentation of waste as a strategy to enhance the performance of single chambered microbial fuel cell (MFC). Int. J. Hydrogen Energy 2011, 36, 13753-13762. [CrossRef]

51. Chandrasekhar, K.; Ahn, Y.-H. Effectiveness of piggery waste treatment using microbial fuel cells coupled with elutriated-phased acid fermentation. Bioresour. Technol. 2017, 244, 650-657. [CrossRef] [PubMed]

52. Pant, D.; Arslan, D.; Van Bogaert, G.; Alvarez-Gallego, Y.; De Wever, H.; Diels, L.; Vanbroekhoven, K. Integrated conversion of food waste diluted with sewage into volatile fatty acids through fermentation and electricity through a fuel cell. Environ. Technol. 2013, 34, 1935-1945. [CrossRef] [PubMed]

53. Ghasemi, M.; Ahmad, A.; Jafary, T.; Azad, A.K.; Kakooei, S.; Daud, W.R.W.; Sedighi, M. Assessment of immobilized cell reactor and microbial fuel cell for simultaneous cheese whey treatment and lactic acid/electricity production. Int. J. Hydrogen Energy 2017, 42, 9107-9115. [CrossRef]

54. Rivera, I.; Bakonyi, P.; Cuautle-Marín, M.A.; Buitrón, G. Evaluation of various cheese whey treatment scenarios in single-chamber microbial electrolysis cells for improved biohydrogen production. Chemosphere 2017, 174, 253-259. [CrossRef]

55. Wenzel, J.; Fuentes, L.; Cabezas, A.; Etchebehere, C. Microbial fuel cell coupled to biohydrogen reactor: A feasible technology to increase energy yield from cheese whey. Bioprocess Biosyst. Eng. 2017, 40, 807-819. [CrossRef]

56. Huang, L.; Logan, B.E. Electricity generation and treatment of paper recycling wastewater using a microbial fuel cell. Appl. Microbiol. Biotechnol. 2008, 80, 349-355. [CrossRef]

57. Kim, T.; An, J.; Jang, J.K.; Chang, I.S. Coupling of anaerobic digester and microbial fuel cell for COD removal and ammonia recovery. Bioresour. Technol. 2015, 195, 217-222. [CrossRef]

58. Zhang, Y.; Liu, M.; Zhou, M.; Yang, H.; Liang, L.; Gu, T. Microbial fuel cell hybrid systems for wastewater treatment and bioenergy production: Synergistic effects, mechanisms and challenges. Renew. Sustain. Energy Rev. 2019, 103, 13-29. [CrossRef]

59. Oh, S.E.; Logan, B.E. Hydrogen and electricity production from a food processing wastewater using fermentation and microbial fuel cell technologies. Water Res. 2005, 39, 4673-4682. [CrossRef]

60. Sharma, Y.; Li, B. Optimizing energy harvest in wastewater treatment by combining anaerobic hydrogen producing biofermentor (HPB) and microbial fuel cell (MFC). Int. J. Hydrogen Energy 2010, 35, 3789-3797. [CrossRef]

61. Varanasi, J.L.; Roy, S.; Pandit, S.; Das, D. Improvement of energy recovery from cellobiose by thermophillic dark fermentative hydrogen production followed by microbial fuel cell. Int. J. Hydrogen Energy 2015, 40, 8311-8321. [CrossRef]

62. Pandit, S.; Balachandar, G.; Das, D. Improved energy recovery from dark fermented cane molasses using microbial fuel cells. Front. Chem. Sci. Eng. 2014, 8, 43-54. [CrossRef]

63. Song, Y.E.; El-Dalatony, M.M.; Kim, C.; Kurade, M.B.; Jeon, B.-H.; Kim, J.R. Harvest of electrical energy from fermented microalgal residue using a microbial fuel cell. Int. J. Hydrogen Energy 2019, 44, 2372-2379. [CrossRef]

64. Sugnaux, M.; Happe, M.; Cachelin, C.P.; Gloriod, O.; Huguenin, G.; Blatter, M.; Fischer, F. Two stage bioethanol refining with multi litre stacked microbial fuel cell and microbial electrolysis cell. Bioresour. Technol. 2016, 221, 61-69. [CrossRef] [PubMed]

65. Kim, B.; Mohan, S.V.; Fapyane, D.; Chang, I.S. Controlling Voltage Reversal in Microbial Fuel Cells. Trends Biotechnol. 2020, 38, 667-678. [CrossRef] [PubMed]

66. Chuda, A.; Ziemiński, K. Challenges in Treatment of Digestate Liquid Fraction from Biogas Plant. Performance of Nitrogen Removal and Microbial Activity in Activated Sludge Process. Energies 2021, 14, 7321. [CrossRef] 